\title{
PERANCANGAN SISTEM INFORMASI PENCARIAN DAN PEMESANAN RUMAH KOS BERBASIS WEB (STUDI KASUS: KOTA BANDAR LAMPUNG)
}

\author{
Arief Budiman $^{1)}$, Lara Sri Wahyuni' ${ }^{2}$, Suharsono Bantun ${ }^{3)}$ \\ ${ }^{1) 2)}$ Sistem Informasi, Universitas Teknokrat Indonesia \\ ${ }^{3}$ Sistem Informasi, Universitas Sembilanbelas November, \\ ${ }^{1) 2)}$ Jl. ZA. Pagar Alam No.9-11, Labuhan Ratu, Kedaton, Kota Bandar Lampung \\ 3) Jl. Pemuda, Tahoa, Kolaka, Kabupaten Kolaka, Sulawesi Tenggara \\ Email: ${ }^{1}$ arief.budiman10@teknokrat.ac.id, ${ }^{2}$ larasriwahyuni17@gmail.com, ${ }^{3)}$ suharsonob@usn.ac.id
}

\begin{abstract}
Abstrak
Rumah kost merupakan sebuah usaha rumahan yang menyediakan tempat atau kamar untuk disewakan kepada yang membutuhkan. Daerah Bandar Lampung ditemukan sekitar 71 (tujuh puluh satu) lebih rumah kost baik yang berupa kamar bedengan dan kamar yang berada di dalam rumah pemilik kost serta variasi harga yang berbeda-beda berdasarkan bentuk dan fasilitas yang ada didalam kamar kost.
\end{abstract}

Pada saat ini di daerah Bandar Lampung, masih ada masyarakat yang belum memanfaatkan teknologi informasi untuk pencarian dan pemesanan rumah kost. Sistem yang sering dipakai, mereka masih harus bertanya kepada teman atau bertanya langsung kepada pemilik rumah kost untuk membandingkan letak, fasilitas maupun harga. Bagi pemilik rumah kost masih mempromosikan rumah kostnya dengan memasang pamflet atau tulisan "Terima kost" di sebuah papan.

Dari permasalahan di atas maka penulis merancang sebuah sistem informasi pencarian dan pemesanan rumah kost berbasis web dengan menggunakan bahasa pemrograman $P H P$, database $M Y S Q L$ dan dirancang menggunakan Unified Modeling Language (UML). Teknik pengumpulan data dalam penelitian ini menggunakan wawancara (interview), pengamatan (observasi), studi literatur, dan dokumentasi. Hasil pengujian kualitas menggunakan ISO 9126 aspek fungsionality yang menunjukkan bahwa sistem melakukan 100\% fungsinya dengan benar dan hasil pengujian kebutuhan user menggunakan ISO 9126 aspek usability diperoleh nilai persentase sebesar $88.36 \%$.

Kata Kunci : database MySQL, ISO 9126, Pencarian Kost, PHP, UML,

\section{Pendahuluan}

Saat ini internet sudah menjadi sarana komunikasi yang penting dan efektif untuk memperoleh berbagai sumber informasi. Internet juga sudah terbukti memberi manfaat untuk masyarakat, salah satunya di bidang bisnis penyedia layanan tempat tinggal atau rumah kost

Berdasarkan observasi langsung dan sampling rumah kost di wilayah Kota Bandar Lampung ditemukan sekitar 71 (tujuh puluh satu) lebih rumah kost, baik yang berupa kamar bedengan maupun kamar yang berada di dalam rumah pemilik kost. Serta variasi harga yang berbeda-beda berdasarkan bentuk dan fasilitas yang ada didalam kamar kost. Banyak masyarakat khususnya para pelajar atau mahasiswa yang akan menjalani studi dari luar kota Bandar Lampung, membuat membuat mahasiswa mencari tempat tinggal sementara untuk di jadikan tempat tinggal mereka sampai studinya selesai.

Berdasarkan hasil wawancara yang dilakukan kepada pemilik kost dan penghuni kost di daerah Bandar Lampung, terdapat masyarakat yang belum memanfaatkan teknologi informasi untuk pencarian dan pemesanan rumah kost. Sistem yang sering dipakai, mereka masih harus bertanya kepada teman atau bertanya langsung kepada pemilik rumah kost untuk membandingkan letak, fasilitas maupun harga. Bagi pemilik rumah kost masih mempromosikan rumah kostnya dengan memasang pamflet atau tulisan "Terima kost" di sebuah papan.

Selain itu, hasil pengamatan terhadap sistem informasi pencarian rumah kost berbasis online, ditemukan beberapa aplikasi online dan situs seperti olx.co.id dan mamikos.com. Sistem tersebut dapat menyajikan informasi tentang pencarian rumah kost berdasarkan wilayah dan detail kost seperti alamat, harga kamar, fasilitas, jenis kost dan nomor kontak pemilik kost. Setelah diamati sistem tersebut hanya menyedikan menu pencarian rumah kost serta detail kost namun belum ada menu pemesanan/booking, sehingga saat pemesanan calon penyewa masih harus datang langsung menemui pemilik kost. Hal tersebut, tentu menyita banyak waktu karena biasanya pemilik kost akan menerima penyewa yang datang terlebih dahulu. 
Sistem ini harus dapat memberikan informasi yang detail dan rinci tentang segala hal yang berhubungan dengan rumah kost. Sistem ini berisi informasi rumah kost seperti, letak rumah kost, gambaran kost, pemilik kost, daftar harga per kost, fasilitas kost dan bagaimana cara memesan/booking.

\section{Pembahasan}

\subsection{Tahapan Penelitian}

Tahapan penelitian merupakan lanjutan dari kerangka penelitian, tahapan penelitian dapat dilihat pada gambar berikut ini:

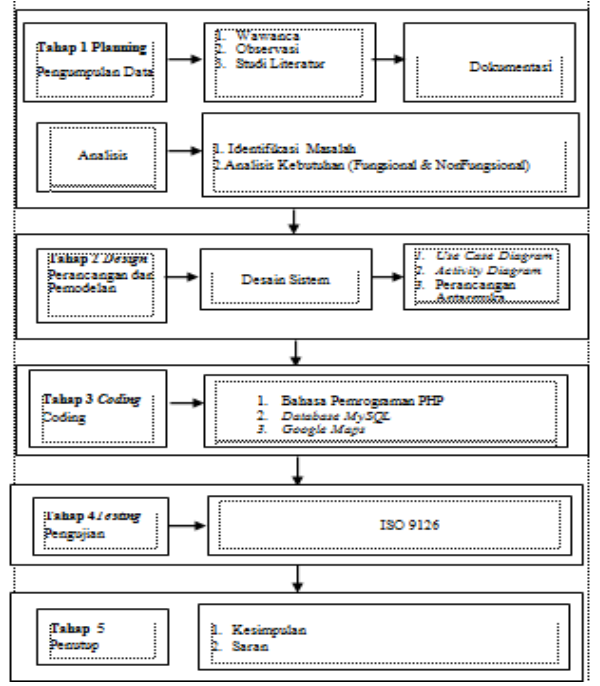

Gambar 1. Tahapan Penelitian

\subsection{Pengumpulan Data}

Teknik pengumpulan data yang dilakukan penulis dalam penelitian ini adalah sebagai berikut :

a. Wawancara

Peneliti akan melakukan wawancara secara langsung dengan pemilik dan penghuni rumah kost. Dari hasil wawancara dapat disimpulkan bahwa pemilik kost umumnya masih mempromosikan rumah kostnya dengan manual seperti memasang tulisan "Terima Kost" di depan rumah.

b. Observasi

Observasi dilakukan dengan mengunjungi dan mengamati secara langsung lokasi tempat kost yang ada di daerah Bandar Lampung. Data yang didapatakan dari hasil observasi yaitu mengenai cara periklanan rumah kost yang dilakukan oleh pemilik kost.

c. Studi Literatur

Studi literatur dilakukan kajian literatur dari beberapa jurnal, E-book, buku-buku referensi dan sumber sumber lain yang berkaitan dan dapat mendukung dalam pembuatan penelitian ini.

d. Dokumentasi
Dokumentasi yang digunakan pada penelitian ini adalah dokumentasi dari kegiatan observasi serta proses wawancara yang dilakukan oleh peneliti.

\subsection{Design}

Rancangan sistem dalam tahap ini digunakan untuk menggambarkan desain sistem yang diusulkan dengan menggunakan pemodelan UML (Unifield Modeling Language) yang berorientasi objek yaitu use case dan activity diagram yang dapat mempermudah pembuatan sistem (Shalahuddin, 2016). Use case sistem pencarian dan pemesanan rumah kost berbasis web pada Kota Bandar Lampung yang akan dibangun, dapat dilihat pada Gambar 2.

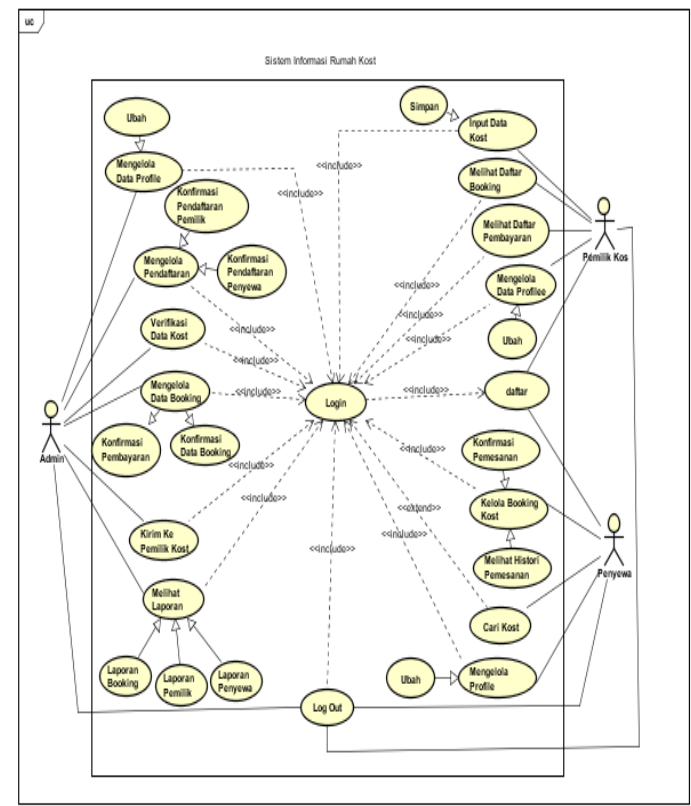

Gambar 2. Use case Diagram

\subsection{Rencana Pengujian ISO 9126}

Pengujian sistem ini akan diuji oleh pemilik kost dan calon penyewa dengan menggunakan metode yang diambil adalah metode pengujian ISO 9126 berdasarkan Functionality dan Usability. Untuk mengukur suatu variabel yang akan diteliti maka peneliti menggunakan instrument penelitian skala likert.

Pada aspek Usability, pengujian menggunkan instrumen penelitian berupa test case dengan skala likert. Skala likert dapat digunakan untuk mengukur sikap, pendapat dan persepsi seseorang atau sekelompok orang tentang fenomena sosial. Dalam penelitian fenomena sosial ini diterapkan secara spesifik oleh penelitian, yang selanjutnya disebut dengan variabel. Dengan adanya skala likert, maka variabel yang akan diukur dijabarkan menjadi indikator variabel, sehingga dapat menjadi titik tolak untuk menyusun instrument yang dapat berupa pernyataan atau pertanyaan (Sugiyono, 2016).

Sedangkan pada aspek functionality, pengujian menggunakan instrumen penelititan berupa test case dengan skala Guttman. Skala Guttman digunakan pada 
penelitian apabila ingin mendapatkan jawaban yang tegas terhadap suatu permasalahan yang ingin ditanyakan (Sugiyono, 2016). Skala pengukuran dengan tipe ini didapat jawaban yang tegas, yaitu "ya-tidak", "benar-salah", "sukses-gagal" dan lain-lain.

Kemudian data yang didapat dianalisis dengan menghitung rata-rata jawaban berdasarkan skor setiap jawaban responden yang ada diangket fungsional suitability. Berdasarkan skor yang telah didapat ditetapkan rumus perhitungan hasil pengujian fungsional suitability sebagai berikut :

$$
\begin{aligned}
& \text { Persentase } \\
& =\frac{\text { skor hasil pengujian }}{\text { skor tertinggi }} \times 100 \%
\end{aligned}
$$

Berdasarkan skor yang telah didapat ditetapkan rumus perhitungan hasil pengujian usability sebagai berikut :

$$
=\frac{\text { Persentase }}{\text { skor hasil pengujian }} \times 100 \%
$$

Hasil perhitungan aspek usability dihitung yang kemudian di tetapkan berdasarkan rentang kriteria kualitas pengujian aspek usability yang dapat dilihat pada Tabel 1.

Tabel 1. Rentang kriteria kualitas pengujian aspek usability

\begin{tabular}{|c|c|l|}
\hline No & Rentang kriteria & \multicolumn{1}{|c|}{ Kriteria } \\
\hline 1 & $0 \%-20 \%$ & Sangat Tidak Layak \\
\hline 2 & $21 \%-40 \%$ & Tidak Layak \\
\hline 3 & $41 \%-60 \%$ & Kurang Layak \\
\hline 4 & $61 \%-80 \%$ & Layak \\
\hline 5 & $81 \%-100 \%$ & Sangat Layak \\
\hline
\end{tabular}

Sumber : (Sugiyono, 2016)

\subsection{Implementasi program}

Implementasi sistem merupakan tahap dimana sistem sudah siap dioperasikan (Anggraeni dan Rivani, 2017). Berikut hasil implementasi rancangan interface:

1. Form Menu Beranda

Pada halaman menu utama dalam website ini merupakan tampilan beranda yang berfungsi untuk menampilkan menu pencarian rumah kost, menu daftar sebagai pemilik kost, menu daftar sebagai penyewa kost, informasi kontak admin, menu tentang website dan menu login bagi pemilik kost dan calon penyewa yang sudah mendaftar yang bisa dilihat oleh pemilik kost dan calon penyewa. Form menu utama dapat dilihat pada Gambar 2.

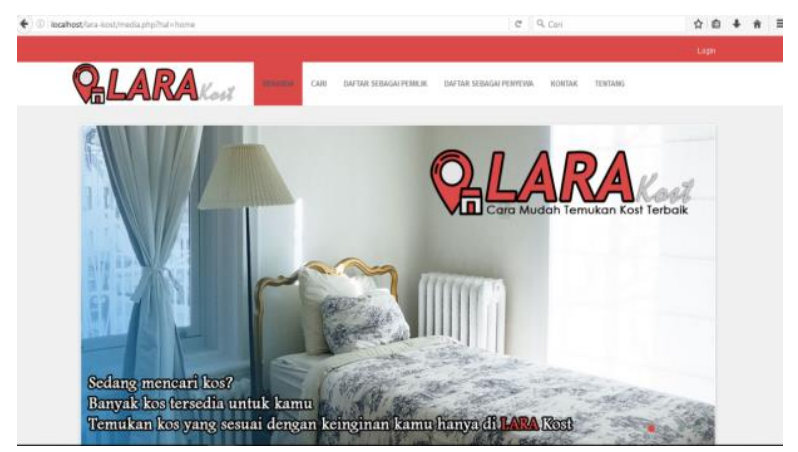

Gambar 3. Menu Utama

2. Form Menu Daftar Sebagai Pemilik

Pada halaman menu daftar akun pemilik dalam website ini, pengguna dapat menginptkan nama pemilik kost, NIK, alamat lengkap, telepon, email, password, konfirmasi password dan upload dokumen KTP/KTM/SIM. Form menu daftar sebagai pemilik dapat dilihat pada Gambar 4.

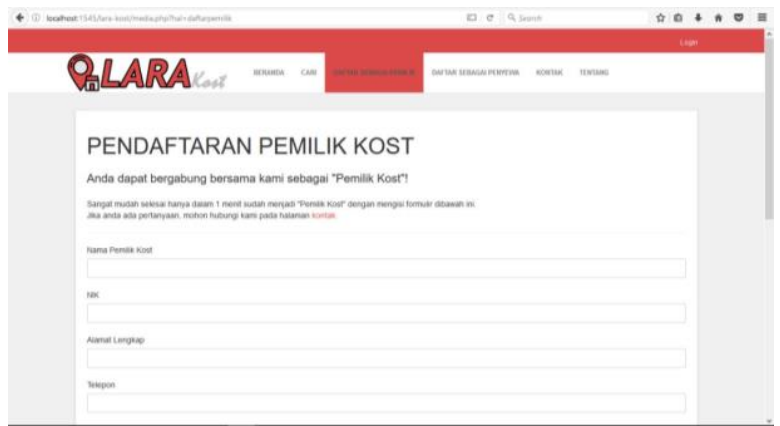

Gambar 4. Menu Daftar Sebagai Pemilik

\section{Form Daftar Sebagai Penyewa}

Pada halaman menu daftar akun penyewa dalam website ini, pengguna dapat menginputkan nama penyewa kost, NIK, alamat lengkap, telepon, email, password, konfirmasi password dan upload dokumen KTP/KTM/SIM. Form menu daftar sebagai penyewa dapat dilihat pada Gambar 5.

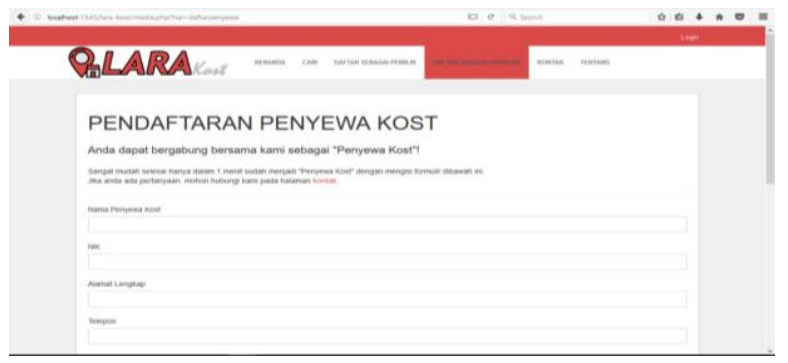

Gambar 5. Menu Daftar Sebagai Penyewa

\section{Form Menu Login}

Pada halaman login dalam website ini, pengguna akan memasukkan email dan juga password untuk 
mengakses sistem, form menu login dapat dilihat pada Gambar 6.

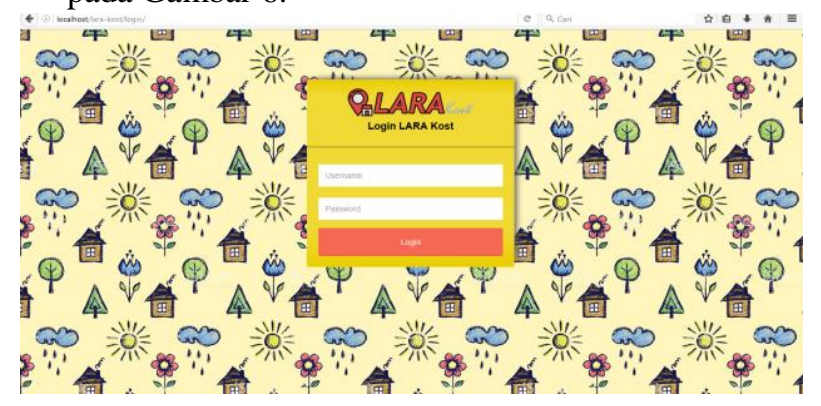

Gambar 6. Menu Login

5. Form Menu Utama Admin

Form menu utama Admin dalam website ini, merupakan tampilan yang berfungsi untuk melihat menu-menu yang akan di akses oleh admin, terdapat beberapa menu seperti verifikasi pendaftaran pemilik, verifikasi pendaftaran penyewa, verifikasi data kost, lihat data booking, konfirmasi transfer, melanjutkan pengiriman uang ke pemilik kost, melihat laporan data pemilik kost, melihat laporan data penyewa kost, dan melihat laporan data booking. Menu utama admin dapat dilihat pada Gambar 7.

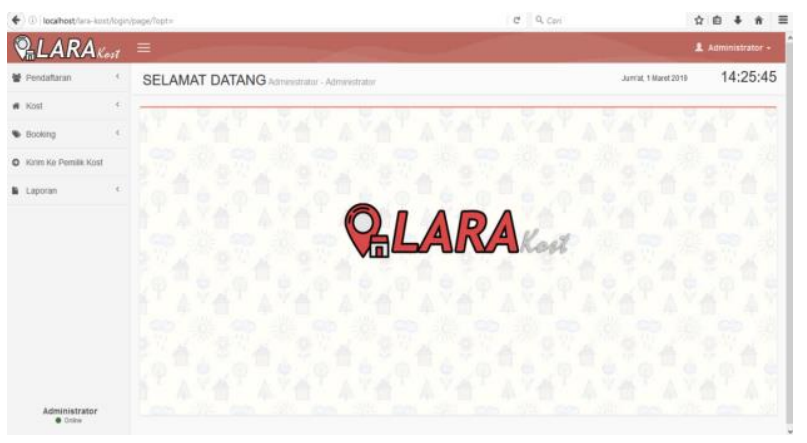

Gambar 7. Menu Utama Admin

6. Form Verifikasi Data Pemilik Kost

Pada halaman verifikasi data pemilik dalam website ini, admin akan melakukan verifikasi data pemilik kost, apabila data sudah benar maka akan di setujui oleh admin namun apabila data salah maka akan ditolak oleh admin. Form verifikasi data pemilik kost dapat dilihat pada Gambar 8.

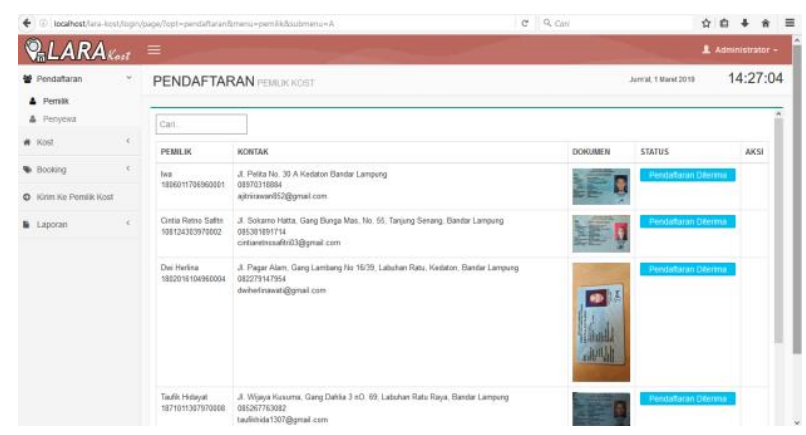

Gambar 8. Menu Verifikasi Data Pemilik Kost

\section{Form Verifikasi Data Penyewa Kost}

Pada halaman verifikasi data pemilik dalam website ini, admin akan melakukan verifikasi data penyewa kost, apabila data sudah benar maka akan di setujui oleh admin namun apabila data salah maka akan ditolak oleh admin. Form verifikasi data penyewa kost dapat dilihat pada Gambar 9.

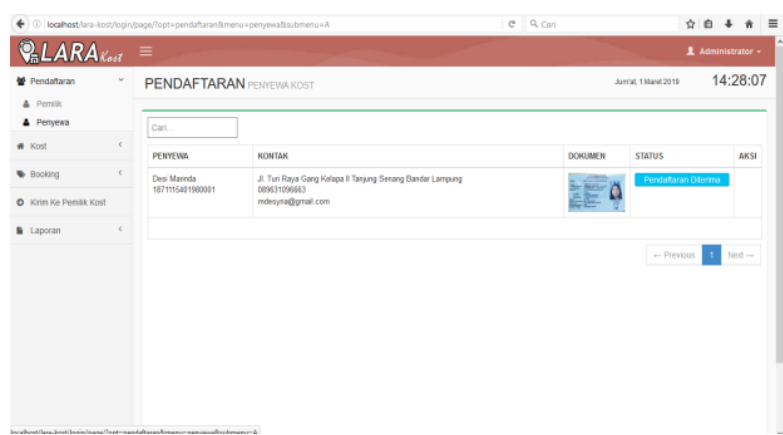

Gambar 9. Menu Verifikasi Data Penyewa Kost

8. Form Verifikasi Data Kost

Pada halaman verifikasi data kost dalam website ini, admin akan melakukan verifikasi data kost, apabila data sudah benar maka akan di setujui oleh admin namun apabila data salah maka akan ditolak oleh admin. Form verifikasi data kost dapat dilihat pada Gambar 10.

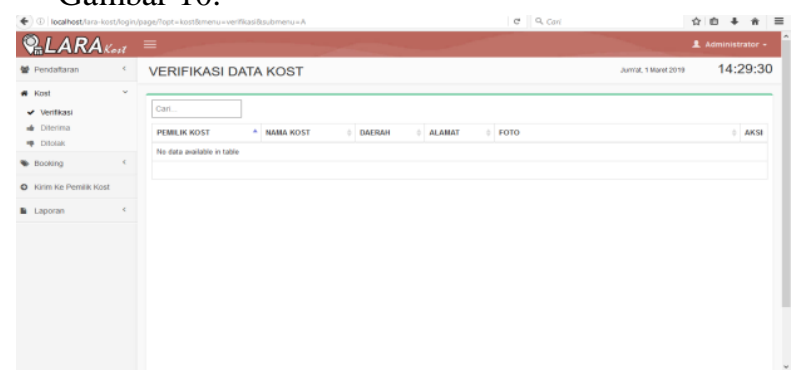

Gambar 10. Form Menu Verifikasi Data Kost

9. Form Verifikasi Daftar Booking

Pada halaman verifikasi daftar booking kost dalam website ini, admin akan melakukan verifikasi daftar booking kost, apabila penyewa sudah melakukan pembayaran maka akan di konfirmasi oleh admin. Form verifikasi daftar booking kost dapat dilihat pada Gambar 11.

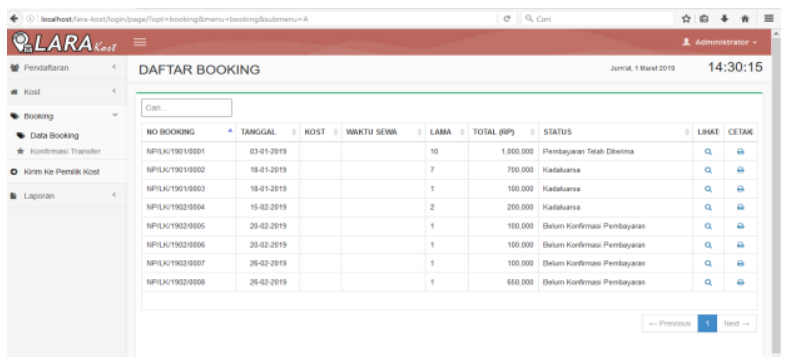

Gambar 11. Menu Verifikasi Daftar Booking Kost 
10. Form Transfer Kirim Ke Pemilik Kost

Pada halaman menu transfer kirim ke pemilik kost dalam website ini, admin akan melakukan pengiriman uang kost ke pemilik, apabila penyewa sudah melakukan pembayaran maka akan di konfirmasi oleh admin. Form verifikasi daftar booking kost dapat dilihat pada Gambar 12.

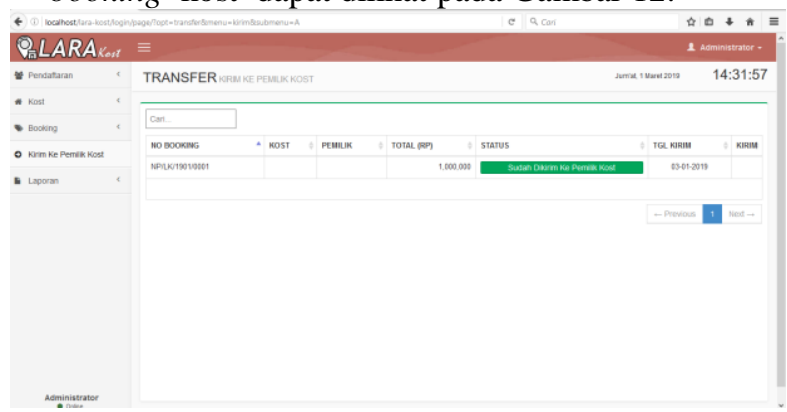

Gambar 12. Menu Transfer Kirim Ke Pemilik Kost

\section{Form Menu Profil Pemilik Kost}

Form menu profile pemilik merupakan tampilan yang berfungsi untuk melihat data diri pemilik dan pemilik dapat melakkan pengeditan data diri. Form menu profile pemilik kost dapat dilihat pada Gambar 13.

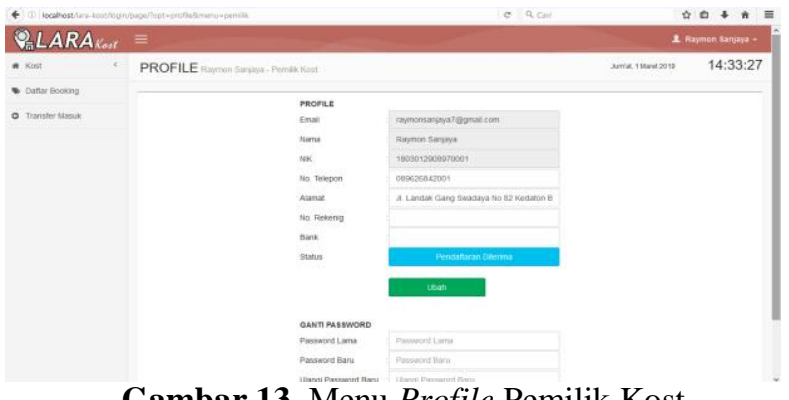

Gambar 13. Menu Profile Pemilik Kost

\section{Form Menu Input Data Kost}

Pada halaman menu input data kost dalam website ini, pengguna dapat menginputkan detail rumah kost seperti nama kost, daerah, alamat lengkap, jenis kost, tipe kamar, ukuran, waktu sewa, harga, kordinat maps, foto kost, foto tagihan listrik dan fasilitas rumah kost. Form menu input data kost dapat dilihat pada Gambar 14.

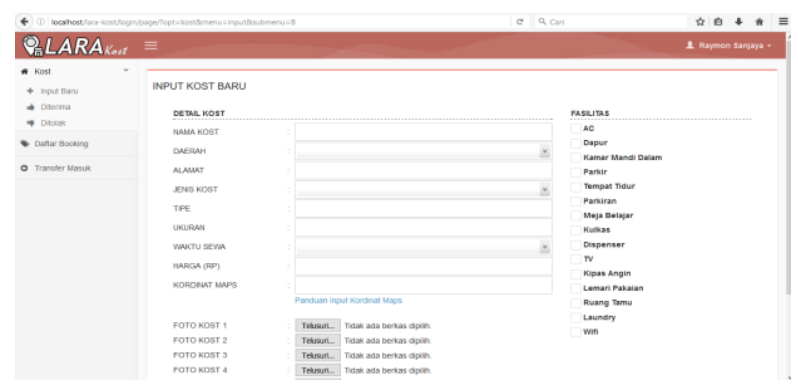

Gambar 14. Menu Input Data Kost

\section{Form Menu Transfer Masuk}

Pada halaman menu transfer masuk dalam website ini, pemilik kost dapat melihat bukti bahwa admin telah melakukan pengiriman uang kost melalui nomor rekening pemilik kost. Form menu input data kost dapat dilihat pada Gambar 15.

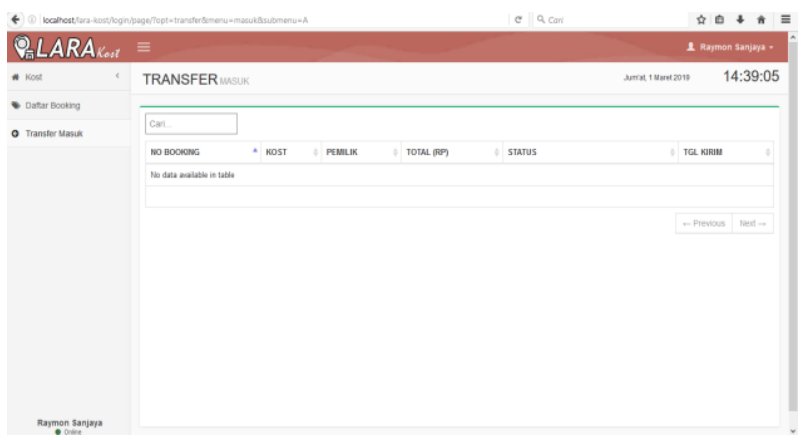

Gambar 15. Form Menu Transfer Masuk

\section{Form Menu Profile Penyewa Kost}

Form menu profile penyewa merupakan tampilan yang berfungsi untuk melihat data diri penyewa dan penyewa dapat melakukan pengeditan data diri. Form menu profile penyewa kost dapat dilihat pada Gambar 16.

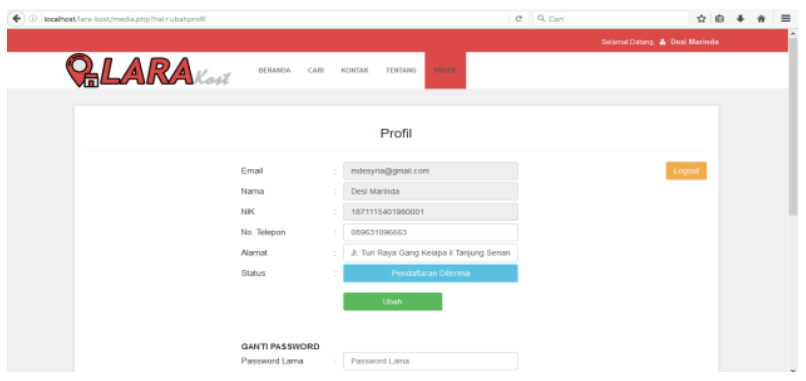

Gambar 16. Menu Profile Penyewa

\section{Form Menu Pencarian Rumah Kost}

Form menu pencarian rumah kost merupakan tampilan yang berfungsi untuk mencari rumah kost yang diinginkan oleh penyewa berdasarkan filter seperti nama kost, daerah, jenis kost, ukuran kost, waktu sewa, fasilitas dan harga. Form menu pencarian rumah kost dapat dilihat pada Gambar 17.

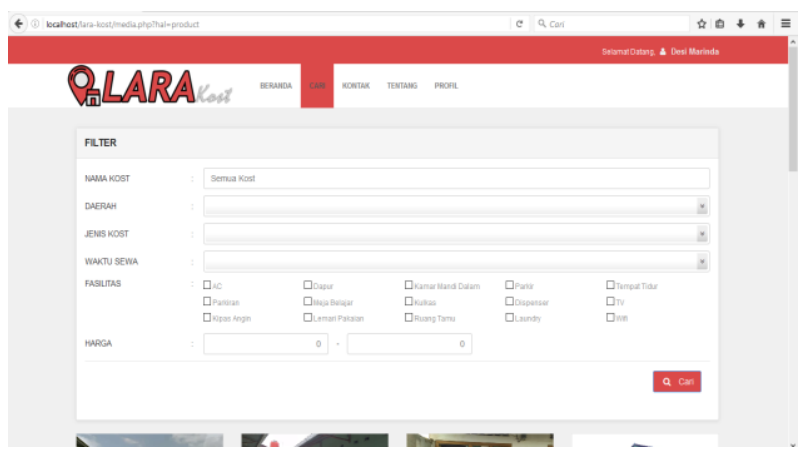




\section{Gambar 17. Menu Pencarian Rumah Kost}

\section{Form Menu Detail Rumah Kost}

Form menu detail rumah kost merupakan tampilan yang berfungsi untuk melihat detail rumah kost seperti fasilitas kamar, nama rumah kost, alamat lengkap, jenis kost, tipe kamar, ukuran, waktu sewa, harga, foto rumah kost dan penilaian yang diberikan oleh penghuni kost sebelumnya. Form menu detail rumah kost dapat dilihat pada Gambar 18.

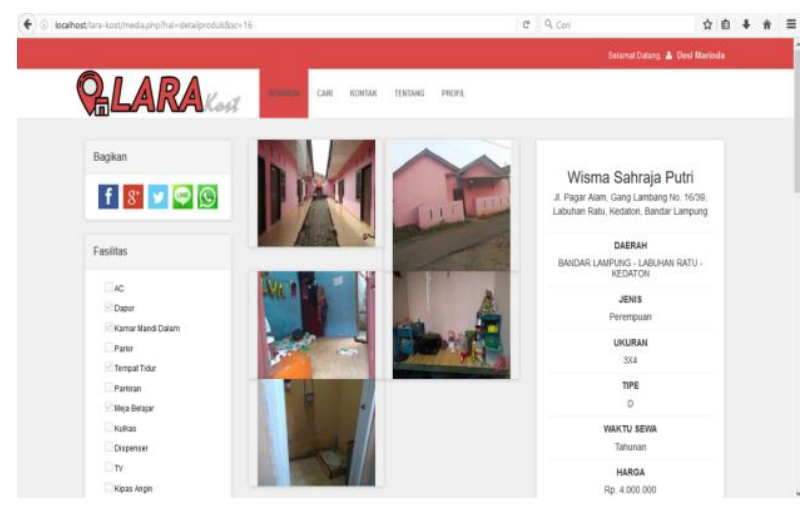

Gambar 18. Detail Rumah Kost

17. Form Menu Detail Pemesanan Rumah Kost

Form menu detail pemesanan rumah kost merupakan tampilan yang berfungsi untuk penyewa melakukan konfirmasi pemesanan rumah kost. Form menu detail pemesanan rumah kost dapat dilihat pada Gambar 20.

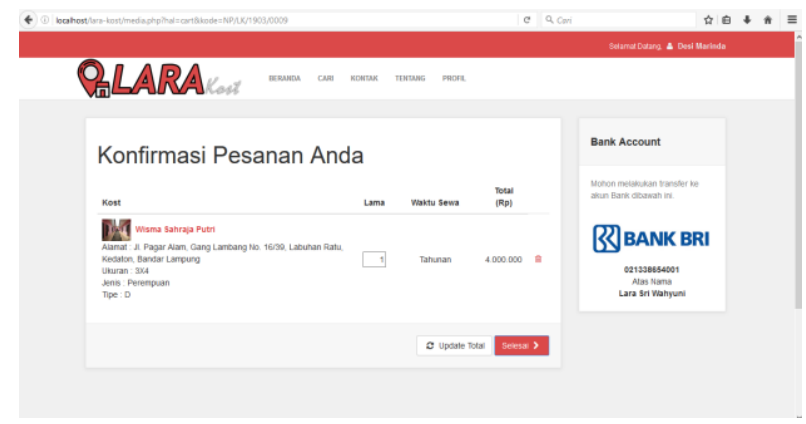

Gambar 20. Menu Detail Pemesanan Rumah Kost

18. Form Menu Pemberitahuan Pemesanan Berhasil

Form menu pemberitahan pemesanan berhasil merupakan tampilan yang berfungsi untuk penyewa melihat pemesanan rumah kost telah berhasil dan dapat melihat history transaksi untk mencetak bukti pemesanan. Form menu pemberitahuan pemesanan berhasil dapat dilihat pada Gambar 21.

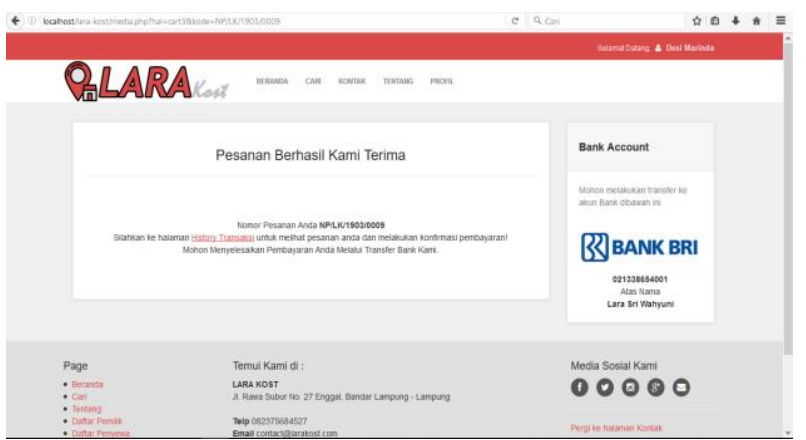

Gambar 21. Menu Pemberitahuan Pemesanan Berhasil

\subsection{Hasil pengujian Functionality}

Pada pengujian functionality kuesioner diisi oleh orang yang memiliki keahlian dalam bidang software engineering untuk mengetahui apakah fungsi - fungsi pada sistem dapat berjalan dengan benar. Jumlah pernyataan dalam kuesioner tersebut yaitu 13 pernyataan dengan menggunakan skala $\mathrm{SS}=5, \mathrm{~S}=4, \mathrm{~N}=3, \mathrm{TS}=2$, $\mathrm{STS}=1$.

Selanjutnya dilakukan perhitungan persentase untuk pengujian aspek functionality yaitu sebagai berikut :

$$
\begin{aligned}
& \text { Persentase } \\
& =\frac{\text { skor hasil pengujian }}{\text { skor tertinggi }} \times 100 \% \\
& =\frac{13}{13} \times 100 \%=100 \%
\end{aligned}
$$

\subsection{Hasil pengujian $U$ sability}

Sedangkan untuk standar skenario penelitian kebutuhan user menggunakan standar kualitas ISO 9126 usability testing, adapun pengujian usability dilakukan terhadap 30 responden melalui media kuisioner yang dapat dilihat pada halaman lampiran. Jumlah pernyataan dalam kuesioner tersebut yaitu 11 pernyataan dengan menggunakan skala $\mathrm{SS}=5, \mathrm{~S}=4, \mathrm{~N}=3, \mathrm{TS}=2, \mathrm{STS}=1$.

Hasil perhitungan yang didapatkan selanjutnya dibandingkan dengan mengkriteria interprestasi skor dengan rentang. Didapatkan hasil kelayakan tiap sub aspek usability dari 30 responden, dengan hasil yang dapat dilihat pada Tabel 2 .

Tabel 2. Hasil Kelayakan sub aspek Usability

\begin{tabular}{|l|l|l|l|}
\hline No & Aspek & Persentase & $\begin{array}{l}\text { Tingkat } \\
\text { Kelayakan }\end{array}$ \\
\hline 1. & Operability & $83,55 \%$ & Sangat Layak \\
\hline 2. & Learnability & $89,77 \%$ & Sangat Layak \\
\hline 3. & Understandability & $87,66 \%$ & Sangat Layak \\
\hline 4. & Attractiveness & $92.22 \%$ & Sangat Layak \\
\hline
\end{tabular}


Selanjutnya dilakukan perhitungan persentase untuk pengujian aspek usability secara keseluruhan dari data hasil pengujian menggunakan rumus :

$$
\begin{aligned}
& \text { Persentase } \\
& \begin{aligned}
\text { usability } & =\frac{\text { skor hasil pengujian }}{\text { skor tertinggi }} \times 100 \% \\
& =\frac{1,458}{1,650} \times 100 \%=88.36 \%
\end{aligned}
\end{aligned}
$$

\subsection{Analisis Hasil Pengujian}

Sistem informasi pencarian dan pemesanan rumah kost berbasis web diuji dalam tahap uji kualitas software ISO 9126 (Functionality dan Usability). Hasil pengujian sistem informasi pencarian dan pemesanan rumah kost berbasis web dapat dilihat pada Tabel 3 .

Tabel 3. Hasil Pengujian Sistem

\begin{tabular}{|l|l|}
\hline \multicolumn{1}{|c|}{ Aspek } & \multicolumn{1}{c|}{ Hasil } \\
\hline Functionality & $\begin{array}{l}\text { Sistem dapat melakukan 100\% } \\
\text { fungsinya dengan benar }\end{array}$ \\
\hline Usability & $\begin{array}{l}\text { Pengujian aspek } \text { usability } \\
\text { diperoleh nilai persentase sebesar } \\
88.36 \%\end{array}$ \\
\hline
\end{tabular}

Berdasarkan Berdasarkan Tabel 3, didapat hasil analisis hasil pengujian:

\section{Analisis Hasil Functionality}

Berdasarkan angket yang diisi oleh orang yang memiliki keahlian dalam bidang softwate engineering, menunjukan hasil bahwa fungsi fungsi pada sistem informasi pencarian dan pemesanan rumah kost berbasis web dapat berjalan dengan benar, tidak adanya tombol yang tidak berfungsi dan tombol memunculkan perintah yang sesuai.

2. Analisis Hasil Usability

Pada hasil usability yang diisi oleh 30 responden menunjukkan bahwa sistem informasi pencarian dan pemesanan rumah kost berbasis web sangat bagus dalam penggunaan, operasi yang sangat mudah, dapat membantu dalam pengolahan data pencarian dan pemesan rumah kost, informasi mudah dipahami.

\section{Kesimpulan}

Sistem informasi pencarian dan pemesanan rumah kost berbasis web di kota Bandar Lampung dibuat menggunakan bahasa pemograman PHP, database MySQL dan dirancang dengan pemrograman berorientasi objek yaitu usecase dan activity diagram, yang dapat diimplementasikan sesuai dengan kebutuhan pengguna dalam mendapatkan informasi detail rumah kost yang ditunjukan pada menu cari dimana para pencari rumah kost dapat menemukan rumah kost berdasarkan filter daerah, jenis kost, ukuran, waktu sewa, fasilitas dan harga.

Sistem informasi pencarian dan pemesanan rumah kost berbasis web di kota Bandar Lampung yang telah dibuat dapat membatu para pencari kost dalam proses pemesanan kamar kost yang ditunjukan pada menu pesan.

Adapun saran yang diberikan yaitu, Diharapkan data dan informasi rumah kost didalam database sistem untuk selalu diperbaharui, sebab akan sangat membantu untuk mempermudah calon penyewa kost dan pemilik kost. Dalam penelitian selanjutnya diharapkan Sistem Informasi Pencarian dan Pemesanan Rumah Kost yang lebih luas, tidak hanya mencakup Kota Bandar Lampung sehingga dapat memberikan informasi yang lebih maksimal.

\section{Daftar Pustaka}

ANGGRAENI, E.Y. DAN RITA IRVANI., 2017.Pengantar Sistem Informasi. Yogyakarta: Andi.

SHALAHUDDIN, M., 2016. Rekayasa Perangkat Lunak Terstruktur dan Berorientasi Objek. Bandung: Informatika Bandung

SUGIYONO, 2016. Metode Penelitian Kuantitatif, Kualitatif, Dan R\&D. Bandung: Alfabeta. 